\title{
Distribution of Muscarinic Cholinergic (mACh) Receptors in the Rat Spinal Cord: In vitro Quantitative Autoradiographic Investigation
}

By

\section{Kiminao MIZUKAWA, Nagayasu OTSUKA, Kumiko HABA* and Norio OGAWA*}

\author{
Department of Anatomy and *Institute for Neurobiology, \\ Okayama University Medical School, \\ Okayama 700, Japan
}

-Received for Publication, July 22, 1988-

\begin{abstract}
Key words: Muscarinic cholinergic receptor, Quinuclidinylbenzilate (QNB) binding site, Rat spinal cord, Autoradiography
\end{abstract}

\begin{abstract}
Summary: The binding of ${ }^{3} \mathrm{H}$-labeled L-quinuclidinylbenzilate (QNB) sites was studied in cryosections of the rat spinal cord (cervical, thoracic and lumbar cords) by in vitro macroautoradiography in an attempt to elucidate the distribution of muscarinic cholinergic ( $\mathrm{mACh}$ ) receptors. In this study, transverse sections as well as longitudinal sections of the thoracic cord were employed. A moderately high density of QNB binding sites could be seen in the gray matter of the spinal cord, especially in the marginal regions of the dorsal horn and around motor neurons in the ventral horn. In the lateral horn of the thoracic cord, a moderately high density of QNB binding sites was segmentally observed. By image analysis with a RAS 1000 (Amersham), color coded autoradiographic images which enhanced the small differences in optical density could be easily obtained, and quantitative analysis of the QNB binding sites in small-sized regions of the spinal cord was also performed. The highest densities of $\mathrm{mACh}$ receptors in the spinal cord were localized in the substantia gelatinosa of the dorsal horn and the region of motor neurons of the ventral horn. These findings suggest that while $\mathrm{mACh}$ receptors are related with motor functions, they are deeply related with sensory and autonomic functions.
\end{abstract}

Several neuroanatomical and neuropharmacological studies have demonstrated that acetylcholine functions as a neurotransmitter, and the acetylcholine system has been clarified more in the mammalian spinal cord (Aquilonius et al., 1981; Kimura et al., 1981; Nagata et al., 1982: Ryall, 1983; Silver and Wolstencroft, 1971). During the last few years, progress in radioligand and receptor autoradiographic analysis systems for cholinergic receptors has facilitated studies on the precise distribution of several cholinergic receptors in the mammalian spinal cord and under several experimental and pathological conditions (Charlton et al., 1981; Geary et al., 1985; Gillberg and Aquilonius, 1985; Gillberg et al., 1984; Gillberg and Wiksten, 1986; Kayaalp and Neff, 1980; Palacios et al., 1981;

Send correspondence to: Kiminao Mizukawa, M.D. Department of Anatomy, Okayama University Medical School, 2-5-1 Shikata-cho, Okayama City, Okayama 700, Japan 
Scatton et al., 1984; Seybold, 1985; Seybold and Elde, 1984; Unnerstall et al., 1982; Villiger and Faull, 1985; Wamsley et al., 1984; Whitehouse et al., 1983).

The aim of the present study was to elucidate the distribution of muscarinic cholinergic $(\mathrm{mACh})$ receptors in transverse as well as longitudinal sections of the rat spinal cord by the in vitro macro-autoradiography method employing ${ }^{3} \mathrm{H}$-labeled Lquinuclidinylbenzilate (QNB) as the ligand for the $\mathrm{mACh}$ receptors. Quantitative evaluation of the regional distribution of $\mathrm{mACh}$ receptors was also performed using an image analysis system.

\section{Materials and Methods}

Four adult male albino rats (Wistar strain; body weight, 200-300 g) were used in this study. They were anethetized by intraperitoneal injection of Nembutal $(0.1$ $\mathrm{mg} / 100 \mathrm{~g}$ body weight) and killed by decapitation. The spinal cord was removed immediately, dissected into the cervical, thoracic and lumbar cords, rapidly frozen on crushed dry-ice and cut into $12 \mu \mathrm{m}$ thick sections on a cryostat in transverse and longitudinal directions. These sections were thaw-mounted on chrome alum gelatin coated slides and dried completely. The sections on the slide glasses were preincubated twice for 2-4 min in ice-cold $50 \mathrm{mM}$ Tris/ $\mathrm{HCl}$ buffer (pH 7.6). After the preincubation, they were incubated in $50 \mathrm{mM}$ Tris/ $\mathrm{HCl}$ buffer containing $1 \mathrm{nM}{ }^{3} \mathrm{H}-\mathrm{QNB}$ (specific activity, 46 Curies/mmol; Amersham, Japan), a potent muscarinic cholinergic antagonist, at $20^{\circ} \mathrm{C}$ for $2 \mathrm{~h}$ with or without $1 \mu \mathrm{M}$ atropine. Nonspecific binding was determined by incubating the sections and the ${ }^{3} \mathrm{H}-\mathrm{QNB}$ in the presence of excess $(1 \mu \mathrm{M})$ atropine. After this incubation, the slide glasses were rinsed twice with the same Tris/ $\mathrm{HCl}$ buffer, and the slides were dried in a stream of cold air. They were secured with strips of double-sided adhesive tape so that the backs of the slides adhered to a hard board in a cassette. A sheet of Hyperfilm $-{ }^{3} \mathrm{H}$ (Amersham, CEA, AB, Sweden) was pressed so as to contact the tissue sections and autoradiographic micro-scales (Amersham, Japan) on the slides, and the cassette was closed in a dark room. After exposure for 3 weeks at $4^{\circ} \mathrm{C}$ in the dark room, the film was developed for $7 \mathrm{~min}$ at $20^{\circ} \mathrm{C}$ in Microdol X (Kodak), fixed for $10 \mathrm{~min}$, washed in running water and dried in air. The distribution of $\mathrm{mACh}$ receptors was revealed on the films. The films were placed on a photographic illumination apparatus, the autoradiograms were processed with a receptor autoradiography image analysis system (Amersham, RAS 1000) and several color coded autoradiographic images were obtained. Furthermore, quantitative analysis of the concentration of QNB binding sites in the dorsal, lateral and ventral horns of each of the segmental spinal cords was performed respectively.

\section{Results}

We observed a moderately high density of QNB binding sites in the gray matter of the spinal cord, but could not obtain positive autoradiograms for QNB binding in the white matter. Fig. 1 shows that the QNB binding sites for $\mathrm{mACh}$ receptor were most densely distributed in the dorsal horn, especially in the marginal regions (i.e. substantia gelatinosa), and ventral horn in transverse sections of the cervical, thoracic and lumbar spinal cord, respectively. The patterns of distribution of QNB binding sites were similar in the cervical, thoracic and lumbar spinal cords. Fig. 2 shows autoradiograms of transverse (A) and longitudinal sections (B) of the thoracic cord. In longitudinal sections of the thoracic cord, it was apparent that the densities of QNB binding sites occurred segmentally in 
Table 1. Concentration of QNB binding sites for $\mathrm{mACh}$ receptors in the rat spinal cord

\begin{tabular}{lcccc}
\hline & & \multicolumn{3}{c}{$\begin{array}{c}\text { Specific binding sites } \\
\text { of each region } \\
\text { (DPMS/mg) }\end{array}$} \\
\cline { 3 - 5 } & (n) & $\begin{array}{c}\text { Dorsal } \\
\text { horn }\end{array}$ & $\begin{array}{c}\text { Lateral } \\
\text { horn }\end{array}$ & $\begin{array}{c}\text { Ventral } \\
\text { horn }\end{array}$ \\
\hline $\begin{array}{l}\text { Cervical } \\
\text { cord }\end{array}$ & $(16)$ & $41,747 \pm 4,699$ & - & $40,438 \pm 4,017$ \\
$\begin{array}{l}\text { Thoracic } \\
\text { cord }\end{array}$ & $(16)$ & $41,980 \pm 7,335$ & $39,321 \pm 9,488$ & $36,928 \pm 7,173$ \\
$\begin{array}{l}\text { Lumbar } \\
\text { cord }\end{array}$ & $(16)$ & $48,403 \pm 8,563$ & & $43,513 \pm 5,400$ \\
\hline
\end{tabular}

$n$ is the number of sections used for quantitative analysis from 4 experimental animals. Each value is expressed as the mean \pm S.E.M.

patches along the lateral aspect of the lateral horn (Fig. 2B). Fig. 3 shows color coded autoradiographic images of thoracic and lumbar spinal cords processed with the image analysis system. In this way, small differences in the optical densities could be enhanced, so facilitating easy recognition of the differences in optical densities. Quantitative analysis of the concentration of QNB binding sites in the dorsal horn, ventral horn and lateral horn of the cervical, thoracic and lumbar spinal cords was undertaken respectively (Table 1 ). The highest concentration was observed in the dorsal horn, followed by the ventral horn. The lateral horn of the thoracic cord exhibited the widest range of variance which reflected a segmental distribution of QNB binding sites.

\section{Discussion}

Previous studies (Gillberg et al., 1984; Scatton et al., 1984; Seybold, 1985; Seybold and Elde, 1984; Villiger and Faull, 1985; Wamsley et al., 1984) have demonstrated that QNB binding sites are distributed in the dorsal horn and ventral horn of the spinal cord of several mammalian species including human beings. Most of our findings agreed well with the results of these previous investigations. In the present study, furthermore, we clearly revealed a segmental distribution of QNB binding sites in the lateral horn of the rat thoracic cord. Such segmental high densities of QNB binding sites were very similar to the beaded arrangement of acetylcholinesterase staining observed in the intermedio-medial nucleus (Silver and Wolstencroft, 1971). The densities of QNB binding sites in the gray matter of the spinal cord are not so high in comparison with those of the cerebral cortex and striatum areas (Mizukawa et al., 1987). The quantitative analysis undertaken in this study showed that the densest distribution of QNB binding sites for $\mathrm{mACh}$ receptors was the dorsal horn, especially in the substantia gelatinosa area, followed by the lateral horn of the thoracic cord and the ventral horn. By employing in vitro macro-autoradiography, resolution for two dimensions becomes higher than that in conventional radiolabeled assay. As a result of image analysis with the RAS 1000 , color coded autoradiographic images, which enhanced small differences in optical density, could be easily obtained and showed 
the differences in an attractive manner. Moreover, with the progress of computer image analysis and the use of standard microscales for autoradiography (Geary et al., 1985; Palacios et al., 1981; Unnerstall et al., 1982), it has become easy to perform quantitative analysis for very small regions which are difficult to punch out, such as the substantia gelatinosa or lateral horn of the thoracic cord, for biochemical assay and/or radiolabeled assay in receptor binding studies.

It has been demonstrated that acetylcholine exists in the motor neurons of the ventral horn by both enzyme histochemistry and immunohistochemistry. Acetylcholine has been considered to act mainly for motor function in the motor neurons of the ventral horn, so that motor function is deeply related with the mACh receptor. According to our results, the mACh receptor is more deeply related with sensory function in the rat spinal cord, simultaneously.

\section{Acknowledgments}

The authors wish to thank to Messrs. K. Takeuchi and Y. Someya of Amersham, Japan, for offering the use of the RAS 1000 and providing technical help. This work was supported in part by grants from the Ministry of Education of the Japanese Government.

\section{References}

1) Aquilonius, S.-M., Eckernäs, S.- $\AA$. and Gillberg, P.-G.: Topographical localization of choline acetyltransferase within the human spinal cord and a comparison with some other species. Brain Research, 211: 329-340, 1981.

2) Charlton, G., Brennan, M.J.W. and Ford, D.M.: Alterations in neurotransmitter receptor binding in the spinal cord after transection. Brain Research, 218: 372-375, 1981.

3) Geary, II, W.A., Toga, A.W. and Wooten, G.F.: Quantitative film autoradiography for tritium: methodological considerations. Brain Research, 337: 99-108, 1985.
4) Gillberg, P.-G. and Aquilonius, S.-M.: Cholinergic, opioid and glycine receptor binding sites localized in human spinal cord by in vitro autoradiography: changes in amyotrophic lateral sclerosis. Acta Neurol. Scand., 72: 299-306, 1985.

5) Gillberg, P.-G., Nordberg, A. and Aquilonius, S.-M.: Muscarinic binding sites in small homogenates and in autoradiographic sections from rat and human spinal cord. Brain Research, 300: 327-333, 1984.

6) Gillberg, P.-G. and Wiksten, B.: Effects of spinal cord lesions and rhizotomies on cholinergic and opiate receptor binding sites in rat spinal cord. Acta Physiol. Scand., 126: 575-582, 1986.

7) Kayaalp, S.O. and Neff, N.H.: Regional distribution of cholinergic muscarinic receptors in spinal cord. Brain Research 196: 429-436, 1980.

8) Kimura, H., McGeer, P.L., Peng, J.H. and McGeer, E.G.: The central cholinergic system studied by choline acetyltransferase immunohistochemistry in the cat. J. Comp. Neurol., 200: 151-201, 1981.

9) Mizukawa, K., Ogawa, N., Sora, Y.H. and Sora, I.: Alterations of the muscarinic cholinergic ( $\mathrm{mACh}$ ) receptors in the striatum of the MPTP-induced parkinsonian model in mice: in vitro quantitative autoradiographical analysis. Neuroscience Letters, 81: 105-110, 1987.

10) Nagata, Y., Okuya, M., Watanabe, R. and Honda, M.: Regional distribution of cholinergic neurons in human spinal cord transections in the patients with and without motor neuron disease. Brain Research, 244: 223-229, 1982.

11) Palacios, J.M., Niehoff, D.L. and Kuhar, M.J.: Receptor autoradiography with tritium-sensitive film: potential for computerized densitometry. Neuroscience Letters, 25: 101-105, 1981.

12) Ryall, R.W.: Cholinergic transmission in the spinal cord. In R.A. Davidoff (Ed.) Handbook for the Spinal Cord, Vol. I. Marcel Dekker, New York, pp. 203-240, 1983.

13) Scatton, B., Dubois, A., Javoy-Agid, F. and Camus, A.: Autoradiographic localization of muscarinic cholinergic receptors at various segmental levels of the human spinal cord. Neuroscience Letters, 49: 239-245, 1984.

14) Seybold, V.S.: Distribution of histaminergic, muscarinic and serotonergic binding sites in cat spinal cord with emphasis on the region surrounding the central canal. Brain Research, 342: 291-296, 1985. 
15) Seybold, V.S. and Elde, R.P.: Receptor autoradiography in thoracic spinal cord: correlation of neurotransmitter binding sites with sympathoadrenal neurons. J. Neuroscience, 4: 2533-2542, 1984.

16) Silver, A. and Wolstencroft, J.H.: The distribution of cholinesterases in relation to the structure of the spinal cord in the cat. Brain Research, 34: 205-227, 1971.

17) Unnerstall, J.R., Niehoff, D.L., Kuhar, M.J. and Palacios, J.M.: Quantitative receptor autoradiography using $\left[{ }^{3} \mathrm{H}\right]$ Ultrofilm: application to multiple benzodiazepine receptors. J. Neuroscience Methods, 6: 59-73, 1982.
18) Villiger, J.W. and Faull, R.L.M.: Muscarinic cholinergic receptors in the human spinal cord: differential localization of $\left[{ }^{3} \mathrm{H}\right]$ pirenzepine and $\left[{ }^{3} \mathrm{H}\right]$ quinuclidinylbenzilate binding sites. Brain Research, 345: 196-199, 1985.

19) Wamsley, J.K., Zarbin, M.A. and Kuhar, M.J.: Distribution of muscarinic cholinergic high and low affinity agonist binding sites: a light microscopic autoradiographic study. Brain Research Bulletin, 12: 233-243, 1984.

20) Whitehouse, P.J., Wamsley, J.K., Zarbin, M.A., Price, D.L., Tourtellotte, W.W. and Kuhar, M.J.: Amyotrophic lateral sclerosis: alterations in neurotransmitter receptors. Ann. Neurol., 14: 8-16, 1983. 


\section{Explanation of Figures}

\section{Plate I}

Fig. 1. Autoradiograms of QNB binding sites in transverse sections of the rat spinal cord. Bar $=0.5 \mathrm{~mm}$. C: cervical cord, T: thoracic cord, L: lumbar cord, DH: dorsal horn; LH: lateral horn; VH: ventral horn. A high concentration of QNB binding sites for $\mathrm{mACh}$ receptors is observed in the dorsal horn, especially in the substantia gelatinosa, and in the ventral horn. 


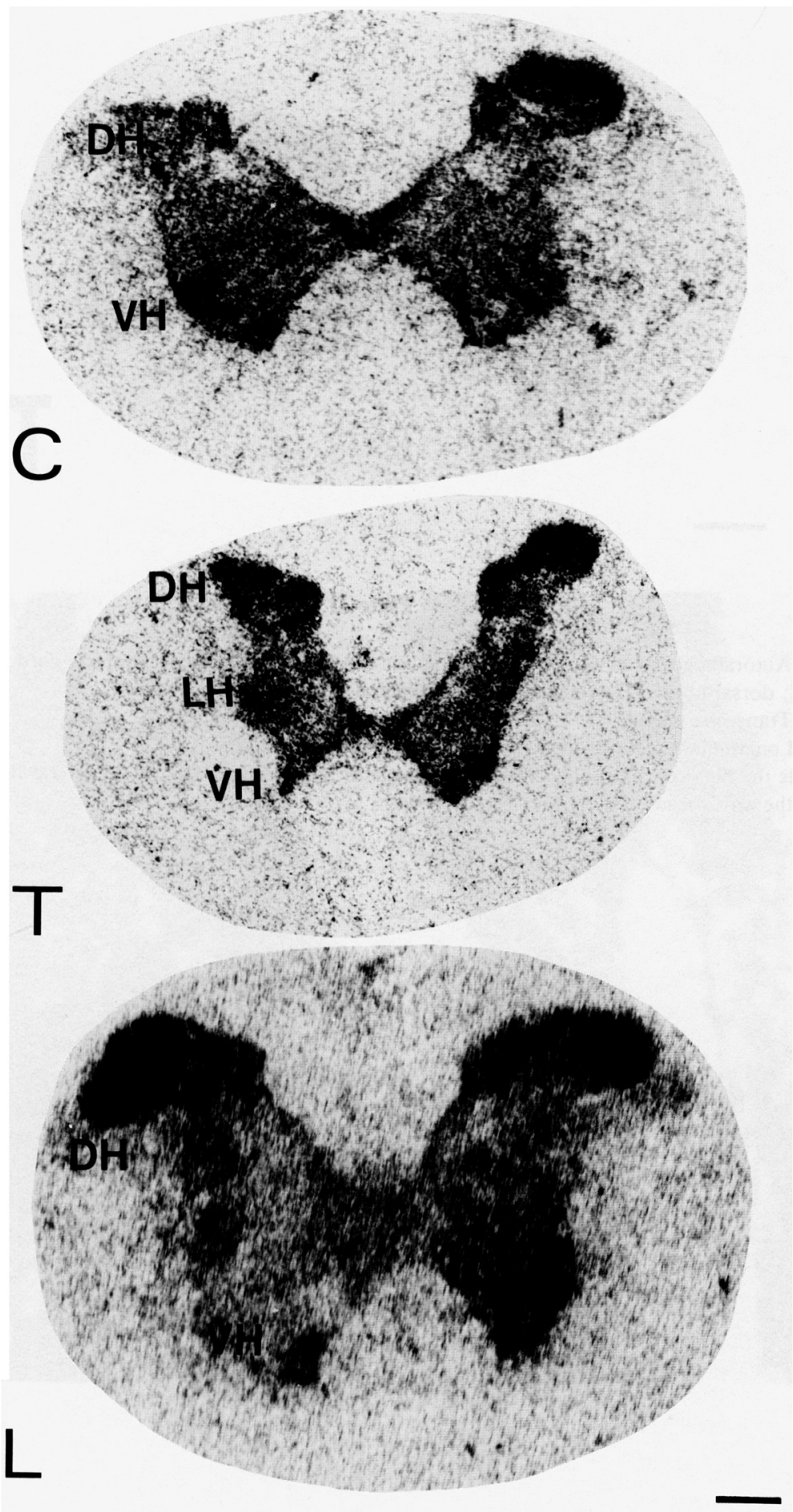


Plate II

Fig. 2. Autoradiograms of QNB binding sites for $\mathrm{mACh}$ receptors in the thoracic cord. Bars $=0.5 \mathrm{~mm}$. DH: dorsal horn; VH: ventral horn; LH: lateral horn; *: central canal.

A: Transverse section.

B: Longitudinal sections of the lateral horn of the thoracic cord.

Note the high concentration of QNB binding sites found segmentally in the lateral horn, as indicated by the arrowheads. 

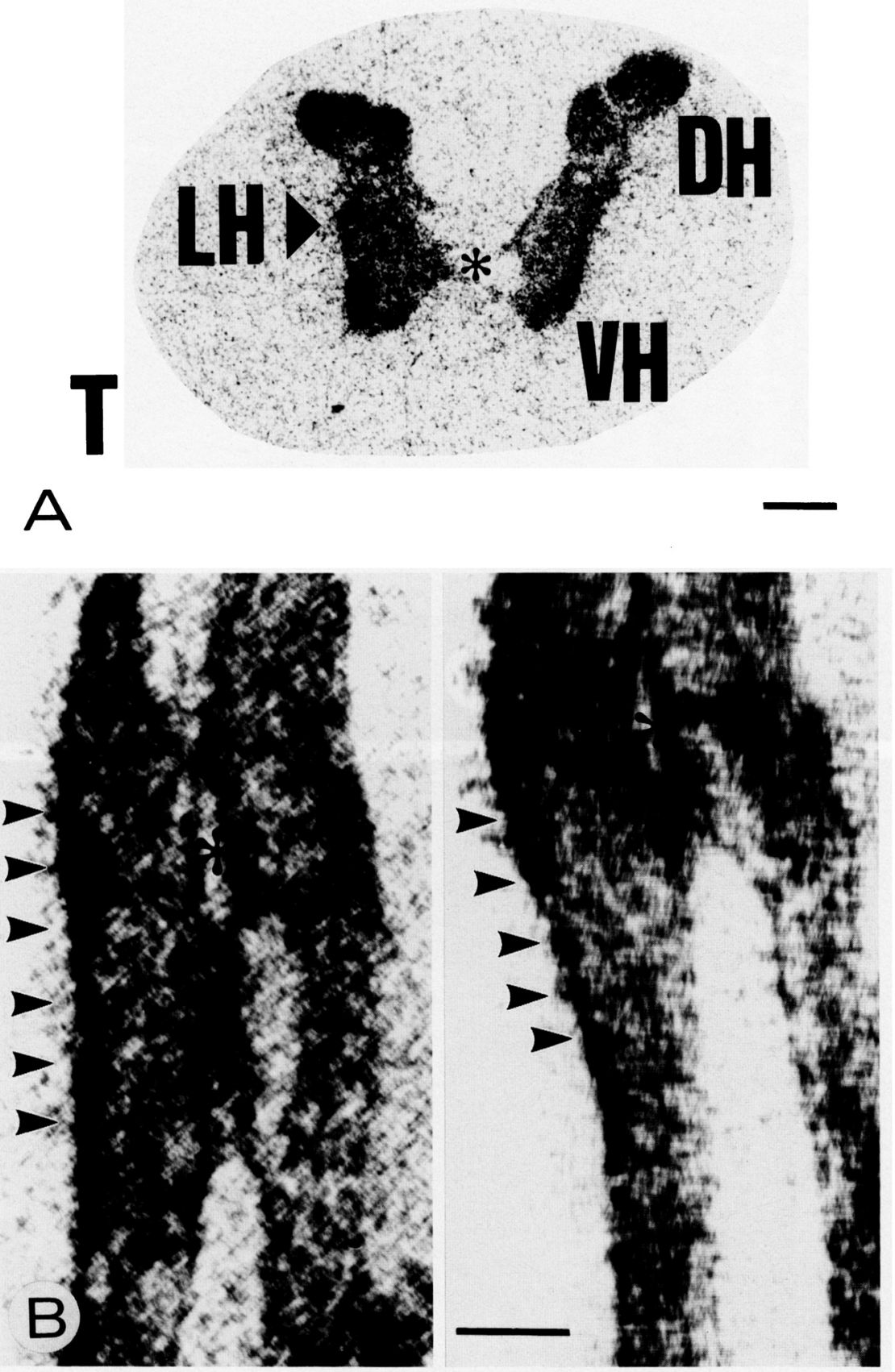


\section{Plate III}

Fig. 3, Color coded autoradiographic images of the thoracic and lumbar cords.

A: Transverse sections of the thoracic cord.

B: Longitudinal section of the thoracic cord.

C: Transverse section of the lumbar cord.

The concentration of QNB binding sites increases with the color sequence shown on the right-hand scale: white- purple- blue- green- yellow- orange- red- black. 

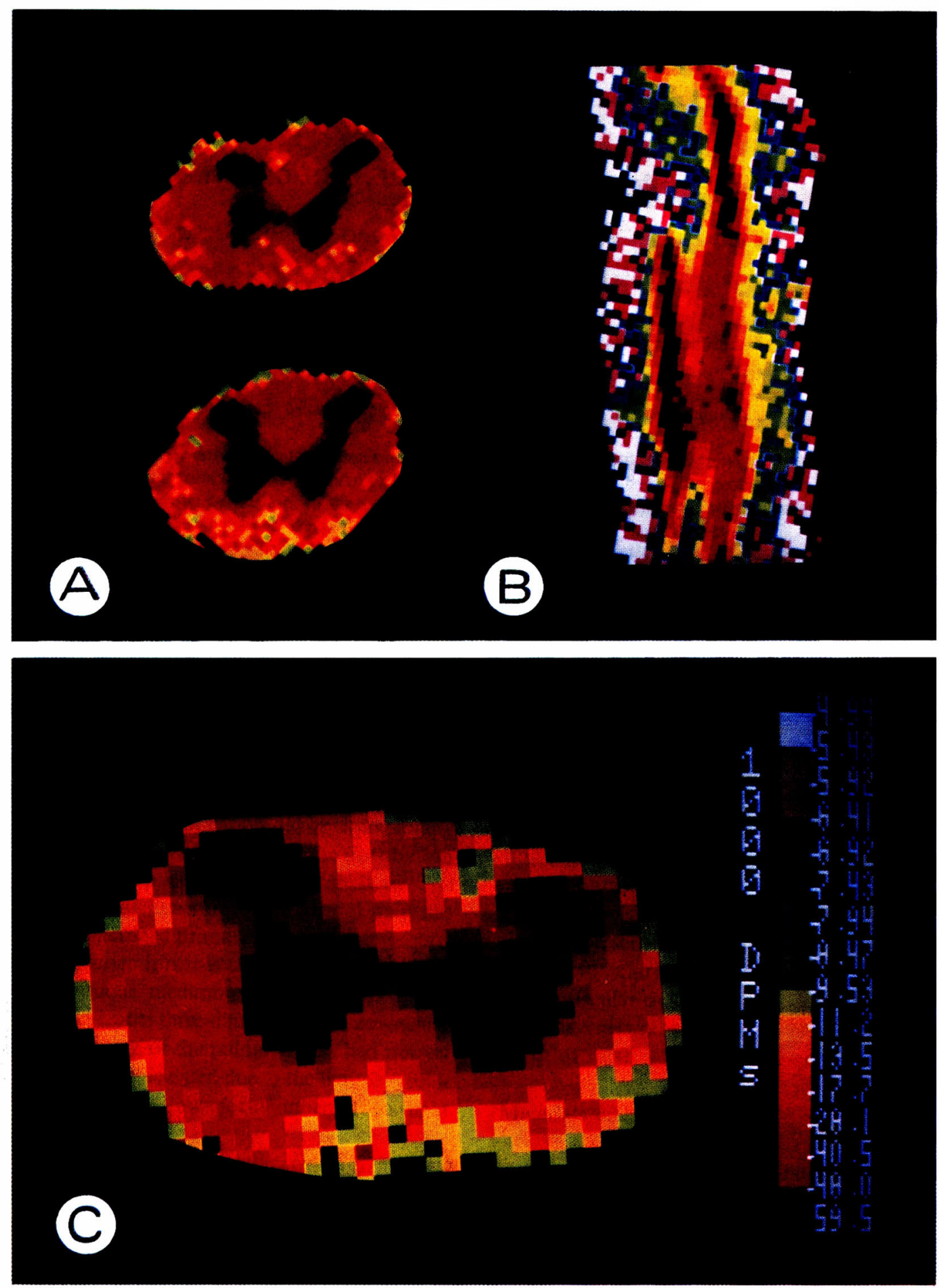